\title{
PENGARUH INTELLECTUAL CAPITAL, GOOD CORPORATE GOVERNANCE, DAN UKURAN PERUSAHAAN TERHADAP KINERJA KEUANGAN PERUSAHAAN PERBANKAN YANG TERDAFTAR DI BURSA EFEK INDONESIA
}

\author{
AFNI ELIANA SARAGIH ${ }^{1}$ \\ UCI TRISNAWATY SIHOMBING ${ }^{2}$ \\ ${ }^{1,2}$ Fakultas Ekonomi Program Studi Akuntansi Universitas Katolik Santo Thomas \\ afni.elianasaragih@gmail.com, ucishombing93@gmail.com
}

\begin{abstract}
ABSTRAK
Penelitian ini bertujuan untuk menguji pengaruh intellectual capital, good corporate governance, dn ukuran perusahaan terhadap kinerja keuangan pada perusahaan perbankan yang terdaftar di Bursa Efek Indonesia periode 2015-2019. Data yang digunakan adalah data sekunder dengan tehnik dokumentasi yang diperoleh melalui annual report yang dipublikasikan di Bursa Efek Indonesia.. Teknik analisis yang digunakan adalah Analisis Regresi Berganda. Hasil uji secara parsial (uji t) menunjukkan intellectual capital berpengaruh positif dan signifikan terhadap kinerja keuangan, good corporate governance berpengaruh positif dan signifikan terhadap kinerja keuangan, dan ukuran perusahaan tidak berpengaruh signifikan terhadap kinerja keuangan. Hasil uji secara simultan (uji F) menunjukkan bahwa variabel intellectual capital, good corporate governance, dan ukuran perusahaan secara bersama-sama berpengaruh positif dan signifikan terhadap kinerja keuangan pada perusahaan perbankan yang terdaftar di Bursa Efek Indonesia (BEI).
\end{abstract}

Kata Kunci : Intellectual Capital, Good Corporate Governance, Ukuran Perusahaan, Kinerja Keuangan.

\section{PENDAHULUAN}

Setiap entitas sejatinya harus mampu menghasilkan laba dalam meningkatkan kinerja keuangan. Dalam memperoleh laba, diperlukan orang-orang yang berpengetahuan yang dapat menciptakan nilai tambah pada perusahaan. Para pelaku bisnis dan karyawan kunci juga semakin memfokuskan diri dalam meningkatkan kinerja perusahaan. Tujuannya tidak kehilangan kepercayaan baik masyarakat atau investor, sehingga laba perusahaan akan terus meningkat.

Dalam Standar Akuntansi Keuangan IAI (2009:13) penghasilan bersih (laba) sering kali digunakan sebagai ukuran kinerja. Terkait dengan pengukuran kinerja, laba pada laporan keuangan sering digunakan sebagai dasar menilai kinerja keuangan perusahaan. Laporan keuangan yang telah dibuat dalam periode tertentu menghasilkan informasi bagi pihak eksternal perusahaan maupun pihak internal untuk pengambilan keputusan. Bagi pihak eksternal yaitu investor, laporan keuangan dapat digunakan untuk pertimbangan dalam pengambilan keputusan dalam rangka penanaman modal. Laporan keuangan tersebut berperan dalam memberikan gambaran mengenai kondisi keuangan. Kinerja keuangan adalah suatu hal yang dijadikan investor untuk melihat dan menilai kinerja serta prospek perusahaan kedepan. Selain itu, penilaian kerja investor untuk melihat dan menilai kinerja serta prospek perusahaan kedepan. Selain itu, penilaian kerja keuangan dilakukan agar pihak masyarakat dan pelanggan yakin serta percaya bahwa perusahaan tersebut memiliki kredibilitas yang baik. Sedangkan bagi pihak internal, kinerja keuangan yang tercermin dari laporan keuangan dapat digunakan untuk pengambilan keputusan dan untuk mengetahui kondisi keuangan. Dengan mengetahui kondisi keuangan, pemilik dan karyawan kunci dapat merencanakan dan mengambil keputusan yang tepat tentang apa yang harus dilakukan kedepan dan 
akan terlihat apakah perusahaan dapat mencapai target yang telah direncanakan sebelumnya atau tidak. Kinerja keuangan dalam penelitian ini diukur dengan menggunakan Return On Assets (ROA), dipilihnya ROA sebagai ukuran kinerja keuangan adalah karena ROA digunakan untuk mengukur efektifitas perusahaan dalam menghasilkan keuntungan dengan memanfaatkan aktiva yang dimilikinya. Semakin besar ROA suatu perusahaan, semakin baik pula posisi perusahaan dari segi penggunaan asset.

Kinerja keuangan perusahaan dapat dipengaruhi oleh berbagai faktor, seperti leverage, aktivitas, konservatisme akuntansi, intellectual capital, good corporate governance, ukuran perusahan dan struktur modal. Dalam penelitin ini, variabel yang digunakan yang mempengaruhi kinerja keuangan perusahaan adalah intellectual capital, good corporate governance dan Ukuran Perusahaan karena variabel-variabel tersebut berfungsi menciptakan nilai tambah dalam perusahaan.

Modal intelektual (intellectual capital) didefenisikan sebagai sumber daya pengetahuan dalam bentuk karyawan, dan teknologi dalam perusahaan yang dapat digunakan dalam proses penciptaan nilai bagi perusahaan (Bukh et al, 2005). Intellectual capital juga dapat dipandang sebagai pengetahuan, informasi, hak kepemilikan intelektual, dan pengalaman yang dapat digunakan untuk menciptakan kekayaan (Stewart, 2012). Intellectual capital atau aset tidak berwujud sering diartikan sama dimana Intellectual capital dan atau aset tidak berwujud sama-sama tidak memiliki wujud fisik. Sebagai peneliti menyebutkan bahwa Intellectual capital dan aset tidak berwujud sama dan seringkali saling menggantikan (Bukh, 2003). Sementara Boekestein (2006) menyatakan bahwa Intellectual capital adalah bagian dari aset tidak berwujud (intangible assets)

Di Indonesia, intellectual capital (IC) mulai berkembang terutama setelah munculnya PSAK No. 19 (revisi: 2000) tentang aktiva tidak berwujud. Meskipun tidak dinyatakan secara eksplisit sebagai IC, namun lebih kurang IC telah mendapat perhatian. Menurut PSAK No. 19, aktiva tidak berwujud adalah aktiva non-moneter yang dapat diidentifikasi dan tidak mempunyai wujud fisik serta dimiliki untuk digunakan dalam menghasilkan atau menyerahkan barang atau jasa, disewakan kepada pihak lainnya, atau untuk tujuan adminstratif (IAI, 2009). PSAK No. 19 paragraf 09 menyebutkan beberapa contoh dari aset tidak berwujud seperti ilmu pengetahuan dan teknologi, desain dan implementasi sistem atau proses baru, lisensi, hak kekayaan intelektual, pengetahuan mengenai pasar dan merek dagang (termasuk merek produk). Selain itu juga ditambahkan piranti lunak komputer, hak paten, hak cipta, film gambar hidup, daftar pelanggan, hak pengusahaan hutan, kuota impor, waralaba, hubungan dengan pemasok atau pelanggan, kesetiaan pelanggan, hak pemasaran, dan pangsa pasar.

Dalam dunia perbankan Intellectual capital merupakan hal yang sangat penting. Hal tersebut dikarenakan sektor perbankan mengandalkan kepercayaan dalam mengelola dana, baik dana pemilik maupun dana masyarakat. Perusahaan perbankan membutuhkan tenaga-tenaga profesional dan terampil serta memiliki integritas moral yang baik dan terpercaya. Perbankan diharapkan dapat memperoleh Intellectual capital yang kuat dalam mengantisipasi persaingan masa depan sumber daya manusia yang unggul, kreatif dan memiliki visi jauh kedepan. Lebih lanjut dijelaskan oleh Muna (2014), bahwa globalisasi serta teknologi informasi yang terus berkembang dan berbagai macam inovasi dan persaingan yang ketat, menuntut perusahaan untuk mengubah pola manajemennya yang semula berbasis tenaga kerja (Labor based business) menjadi berbasis pengetahuan (knoledge based business). Melalui penerapan knoledge based business, maka penciptaan nilai perusahaan akan berubah. Berkembangnya perusahaan dapat dilihat dari kemampuan manajemen untuk mengelola sumber daya perusahaan dalam menciptakan nilai perusahaan. Manajemen perusahaan tercermin dari para karyawan yang merupakan penggerak, serta pengambilan keputusan demi keberlangsungan eksistensi perusahaan. 
Intellectual capital (IC) dalam penelitian ini diukur dengan menggunakan metode Value Added Intellectual Coefficient (VAICTM). Metode VAICTM ini dipilih karena metode ini lebih efektif menilai Intellectual capital yang terdiri dari capital employed/ phisical capital, human capital, structural capital, dan metode perhitungan ini dapat diperoleh pada laporan keuangan perusahaan. Menurut teori stakeholder dalam Ulum (2009:6) menyatakan pengelolaan yang baik atas capital employed/ phisical capital, human capital dan structural capital akan menciptakan Value added bagi perusahaan yang kemudian dapat mendorong kinerja keuangan perusahaan. Artinya pengelola,an Intellectual capital yang baik akan menciptakan value added dan meningkatkan kinerja keuangan perusahaan. Teori ini didukung oleh penelitian Arief dkk (2014) yang menemukan bahwa intellectual capital berpengaruh positif signifikan terhadap kinerja keuangan perusahaan.

Faktor selanjutnya yang mempengaruhi kinerja keuangan perusahaan adalah Good Corporate Governance (GCG). Good Corporate Governance merupakan salah satu alat yang dapat digunakan untuk mengawasi jalannya perusahaan agar manajer bertindak sesuai dengan kepentingan para investor sehingga dapat mencegah timbulnya konflik keagenan. Menurut Sutedi (2012:7) GCG adalah seperangkat peraturan yang mengatur hubungan antara pemegang saham, pengurus (pengelola) perusahaan, pihak kreditur, pemerintah, karyawan serta para pemegang saham kepentingan intern dan ekstern lainnya yang berkaitan dengan hak-hak dan kewajiban mereka atau dengan kata lain suatu sistem yang mengatur dan mengendalikan perusahaan. Dengan tujuan untuk menciptakan nilai tambah bagi semua pihak yang berkepentingan.

Komite Nasional Kebijakan Governance (2006) menerbitkan pedoman GCG bagi perusahaan untuk melakukan GCG dengan tujuan diantaranya mengoptimalkan nilai perusahaan bagi pemegang saham dengan tetap memperhatikan pemangku kepentingan lainnya. Sedangkan Bank Indonesia (PBI) No. 8/14/PBI/2006 tentang pelaksanaan GCG bagi bank Umum. Tujuan dikeluarkannya PBI tersebut adalah untuk memperkuat kondisi internal perbankan nasional dalam menghadapi resiko yang semakin kompleks, berupaya melindungi kepentingan stakeholders dan meningkatkan kepatuhan (compliance) terhadap peraturan perundang-undangan yang berlaku serta nilai-nilai etika (ethics values) yang berlaku umum pada industri perbankan.

Peraturan Bank Indonesia No 8/4/PBI/2006 tentang Pelaksanaan Good Corporate Governance (GCG) bagi Bank umum, menyatakan GCG adalah suatu tata kelola Bank yang menerapkan prinsip-prinsip keterbukaan (transparency), akuntabilitas (accountability), pertanggungjawaban (responsibily), independensi (independency), dan kewajaran (fairness), sedangkan Peraturan Otoritas Jasa Keuangan No. 55/POJK.03/2016 tentang penerapan tata kelola bagi Bank umum pasal 1 menyebut tata kelola yang baik adalah suatu tata cara pengelolaan Bank yang menerapkan prinsip-prinsip keterbukaan, akuntabilitas, pertanggungjawaban, indenpendensi, dan kewajaran. Penerapan prinsip-prinsip GCG pada industri perbankan memerlukan perhatian tersendiri, karena karakter dan kompleksitas industri perbankan berbeda dengan industri pada umumnya. Pengelolaan yang tidak sepadan, tidak hati-hati, tidak transparan, penyalahgunaan wewenang, dan belum diterapkannya prinsip-prinsip good corporate governance secara konsisten telah mengakibatkan dilikuidasinya beberapa bank saat krisis ekonomi karena kelangsungan hidupnya tidak dapat dipertahankan.

Good Corporate Governance dalam penelitian ini diukur dengan menggunakan ukuran Dewan Komisaris. Alasan peneliti menggunakan Dewan Komisaris dalam pengukuran Good Corporate Governance (GCG) dalam penelitian ini karena dewan komisaris sebagai organ perusahaan yang bertugas dan bertanggung jawab secara kolektif untuk melakukan pengawasan dan memberikan nasehat kepada direksi dan juga Dewan Komisaris bertanggung jawab mengawasi tindakan manajemen dalam menyususn laporan keuangan perusahaan. 
Ukuran Perusahaan juga merupakan hal yang penting dalam proses pelaporan keuangan. Ukuran perusahaan dalam hal ini diukur dengan melihat seberapa besar aset yang dimiliki oleh sebuah perusahaan. Aset yang dimiliki perusahaan ini menggambarkan hak dan kewajiban serta permodalan perusahaan. Ukuran perusahaan akan berpengaruh terhadap perkembangan perusahaan. Darmawati (2004) menyatakan bahwa perusahaan besar pada dasarnya memiliki kekuatan finansial yang lebih besar dalam menunjang kinerja. Tetapi disisi lain, perusahaan dihadapkan pada masalah keagenan yang lebih besar. Hesti (2010) dalam penelitiannya menemukan bukti bahwa ukuran perusahaan berpengaruh signifikan terhadap kinerja perusahaan. Perusahaan dengan aset yang besar biasanya akan mendapatkan perhatian lebih dari masyarakat.

Penelitian tentang kinerja keuangan dengan variabel yang mempengaruhi intellectual capital, good corporate governance dan ukuran perusahaan telah dilakukan terdiri dari beberapa penelitian. Penelitian dilakukan oleh Pratiwi (2017) tentang pengaruh intelectual capital dan corporate governance (CG) terhadap kinerja keuangan menemukan bahwa CG dan intellectual capital (IC) berpengaruh positif signifikan terhadap kinerja keuangan. Hasil penelitian yang sama ditemukan oleh Tjondro dan Wilopo (2011) yang menguji pengaruh Good Corporate Governance (GCG) terhadap Profitabilitas dan Kinerja Saham Perusahaan Perbankan.

Namun hasil penelitian tidak selau menunjukkan hasil yang konsisten. Nizamullah, dkk (2014) menguji pengaruh penerapan good corporate governance (GCG) terhadap kinerja keuangan. Hasil penelitian tersebut menunjukkan bahwa GCG berpengaruh negatif dan tidak signifikan terhadap kinerja keuangan (ROA). Penelitian Rivandi, dkk (2018) menguji pengaruh corporate governance, intellectual capital, levarage, dan ukuran perusahaan terhadap kinerja keuangan menemukan bahwa GCG, IC, Levarage dan ukuran perusahaan tidak berpengaruh signifikan terhadap kinerja keuangan. Adriana (2014) juga mendukung hasil penelitian tersebut menyatakan bahwa intellectual capital berpengaruh negatif namun tidak signifikan terhadap kinerja keuangan.

Mengingat pentingnya kinerja keuangan bagi perusahaan, penelitian terkait masih perlu terus dikembangkan. Mengetahui faktor-faktor yang mempengaruhi kinerja keuangan perlu terus ditelurusi dan diteliti. Selain itu, dengan melihat hasil penelitian yang berbeda-beda peneliti tertarik untuk menguji beberapa variabel yang mempengaruhi kinerja keuangan. Peneliti menggunakan sektor perbankan sebagai sampel penelitian karena sektor ini menggunakan Intellectual Capital yang sangat tinggi. Di mana asset yang paling banyak dimiliki bukan pada asset berwujud, melainkan pada asset tidak berwujud.

\section{TINJAUAN PUSTAKA DAN PENGEMBANGAN HIPOTESIS}

\subsection{Kinerja Keuangan (Return On Assets)}

Menurut Jumıngan (2006:240) kinerja keuangan merupakan proses pengkajian secara kritis terhadap keuangan perusahaan yaitu review data, menghitung, memberi solusi terhadap keuangan perusahaan pada suatu periode tertentu. Lebih lanjut Jumingan (2006: 239) menjelaskan kinerja keuangan bank merupakan kondisi keuangan bank pada suatu periode tertentu baik menyangkut aspek penghimpunan dana maupun penyaluran dana yang biasanya diukur dengan indikator kecukupan modal, likuiditas, dan profitabilitas bank.

Brigham dan Houston (2012:146) menjelaskan bahwa laporan akuntansi tidak hanya mencerminkan keadaan pada masa lalu, akan tetapi dapat memberikan petunjuk hal-hal yang memiliki arti penting dan kemungkinan yang terjadi di masa mendatang. Rasio profitabilitas ini lah yang mencerminkan hasıl akhir dari seluruh kebijakan keuangan dan keputusan operasional. Lebih lanjut Brigham dan Houston (2012:148) menyebutkan salah satu rasio profitabilitas yaitu pengembalian atas total aset yang merupakan rasio laba bersih setelah bunga dan pajak terhadap total asset (Return on Asset). Dapat diketahui bahwa besar efisiensi operasional perusahaan tergantung dari pengelolaan aset perusahaan. Hal tersebut menggambarkan bagaimana cara 
perusahaan dalam mengoptimalkan penggunaan aset yang dimiliki untuk dapat memaksimalkan laba. Laba bagi setiap perusahaan pendayagunaan aset. Kinerja keuangan yang baik pada akhirnya akan berdampak baik pada pihak intern dan ekstern perbankan.

\subsection{Intellectual Capital}

Menurut Stewart (2002:X) modal intelektual adalah materi intelektual pengetahuan, informasi, hak pemilikan intelektual, pengalaman yang dapat digunakan untuk menciptakan kekayaan. Menurut Bukh et al dalam Ulum (2009:23) Intellectual Capital (IC) didefenisikan sebagai sumber daya bentuk karvawan, pelanggan, proses atau teknologi yang mana perusahaan dapat menggunakannya dalam proses penciptaan nilai bagi perusahaan. Organisation for Economic Cooperation and Development (OECD) Ulum (2009:21) menjelaskan intellectual capital sebagai nilai ekonomi dari dua kategori aset tidak berwujud meliputi organisational yang mengacu pada hal seperti sistem software, jaringan distribusi, dan rantai pasokan serta human capital meliputi sumber daya manusia di dalam organisasi (yaitu sumber daya tenaga kerja) dan sumber daya eksternal yang berkaitan dengan organisasi seperti konsumen dan supplier.

Intellectual capital memiliki beberapa komponen yang merupakan pengembangan dari definisi dan menjadi unsur dalam variabel ini. Stewart (2002:79-81) mengklasifikasikan intellectual capital kedalam tiga bagian, yaitu:

Modal Manusia (Human Capital)

Modal manusia penting karena human capital merupakan sumber daya berupa inovasi, pembaruan pengetahuan, pengalaman, dan keterampilan.

Modal Struktural (Structural Capital)

Modal struktural mengemas modal manusia dan memungkinkannya untuk digunakan berulangulang dalam menciptakan nilai tambah. Modal struktural yang dimaksud berupa database dan teknologi canggih.

Modal Pelanggan (Customer Capital)

Modal pelanggan adalah nilai dari hubungan organisasi dengan orang- orang yang berbisnis dengannya (pelanggan dan pemasok).

\subsection{Good Corporate Governance}

Peraturan Bank Indonesia No 8/4/PBI/2006 tentang Pelaksanaan Good Corporate Governance (GCG) bagi Bank umum, menyatakan GCG adalah suatu tata kelola Bank yang menerapkan prinsip-prinsip keterbukaan (transparency), akuntabilitas (accountability), pertanggungjawaban (responsibily), independensi (independency), dan kewajaran (fairness). Effendi (2009:2) mengartikan Good Gorporate Governance sebagai seperangkat sistem yang mengatur dan mengendalikan perusahaan untuk menciptakan nilai tambah (value added) bagi para pemangku kepentingan. Sedangkan Menurut Sutedi (2011: 1) corporate governance adalah suatu proses dan struktur yang digunakan oleh organ perusahaan (pemegang saham/pemiliki modal, komisarıs/dewan pengawas dan direksi) untuk meningkatkan keberhasilan usaha dan akuntabilitas perusahaan guna mewujudkan nilai pemegang saham dalam jangka panjang dengan tetap memperhatikan kepentingan stakeholder lainnya, berlandaskan peraturan perundang-undangan dan nilai-nilai etika.

Good corporate governance atau tata kelola perusahaan yang baik akan membantu terciptanya hubungan kondusif dan dapat dipertanggungjawabkan diantara elemen dalam perusahaan (dewan komisaris, komisaris independen, dewan direksi, komite audit dan pemegang saham) dalam rangka meningkatkan kınerja perusahaan Forum for Corporate Governance in 
Indonesia (FCGI) menyatakan dalam publikasinya dan menggunakan definisi dari Cadbury Commitee, yaitu seperangkat peraturan yang mengatur hubungan antara pemegang saham, pengurus (pengelola) perusahaan, pihak kreditur, pemerintah, karyawan serta para pemegang kepentingan intern dan ekstern lainnya yang berkaitan dengan hak-hak dan kewajiban mereka, atau dengan kata lain suatu sistem yang mengatur dan mengendalikan perusahaan. Disamping itu FCGI juga menjelaskan, bahwa tujuan dari Corporate Governance adalah untuk menciptakan nilai tambah bagi semua pihak yang berkepentingan (stakeholders). Lebih lanjut dijelaskan FCGI terminologi Corporate Governance dapat dipergunakan untuk menjelaskan peranan dan perilaku dewan direksi, dewan komisaris, pengurus (pengelola) perusahaan dan para pemegang saham. Dalam penelitian ini, komisaris independen dijadikan proksi untuk mengukur GCG.

\subsection{Ukuran Perusahaan}

Indikator yang dapat digunakan sebagai ukuran perusahaan adalah total penjualan, total aktiva, jumlah karyawan, value added, kapitalisasi nilai pasar, dan bebbagai parameter lainnya. Perusahaan besar dapat memiliki masalah keagenan yang lebih besar (karna lebih sulit untuk untuk dimonitor) sehingga membutuhkan Corporate Governance yang lebih baik (Retno dan Priantinah, 2012). Ukuran perusahaan yang besar mengindikasikan bahwa perusahaan tersebut mempunyai aset besar biasanya akan mendapatkan perhatian lebih dari masyarakat.

Namun perusahaan dengan aset yang besar dapat dengan mudah mengakses pasar modal. Dengan adanya kemudahan mengakses pasar modal, perusahaan tersebut memiliki fleksibiltas dan kemampuan mendapatkan dana (Puspitasari dan Ernawati, 2010). Ukuran perusahaan yang besar cenderung membagikan deviden untuk menghindari konflik keagenan antara pihak manajer dan pemilik (Mengginson, 1997), perusahaan besar memiliki kontrol yang lebih baik terhadap kondisi pasar sehingga mereka mampu menghadapi persaingan ekonomi. Selain itu, perusahaan besar memiliki lebih banyak sumber daya untuk meningkatkan profitabilitas perusahaan karena memiliki akses yang lebih baik terhadap sumber informasi eksternal dibandingkan dengan perusahaan kecil.

\subsection{Kerangka Berpikir dan Pengembangan Hipotesis}

\subsubsection{Pengaruh Intellectual Capital terhadap Kinerja Keuangan}

Menurut teori stakeholder dalam bukunya Ulum (2009:6) menyatakan pengelolaan yang baik atas human capital, capital employed/physical capital, dan structural capital akan menciptakan value added bagi perusahaan yang keudian dapat mendorong kinerja keuangan perusahaan. Artinya pengelolaan intellectual capital yang baik akan menciptakan value added dan meningkatkan kinerja keuangan perusahaan Ulum (2016:92) menyatakan semakin besar nilai VAICTM maka kinerja perusahaan semakin baik. Pengukuran Intellectual Capital yang digunakan penulis adalah dengan menggunakan metode VAICTM karena metode ini dinilai lebih efektif dalam mengukur Iniellectual Capital. VAICTM yang terdiri dari sumber daya inielektual berupa sumber daya manusia, modal organisasi, dan modal pelanggan yang dikelola dengan baik oleh perusahaan dapat menciptakan nilai tambah bagi perusahaan itu sendiri.. Semakin tinggi Intellectual Capital, maka semakın tinggi pula Kinerja Keuangan perusahaan.

H1: Intellectual Capital berpengaruh positif dan signifikan terhadap Kinerja Keuangan

\subsubsection{Pengaruh Good Corporate Governance (GCG) terhadap Kinerja Keuangan}

Effendi dalam bukunya "The Power of Good Corporate Governance" menyatakan bahwa pengertian GCG adalah suatu tatanan atau sistem pengendalian internal (internal control) suatu perusahaan yang bertujuan untuk mengelola risiko yang signifikan dalam rangka memenuhi tujuan bisnis, dan itu dilakukan dengan cara pengamanan aset dan peningkatan nilai investasi para pemegang saham dalam jangka waktu yang panjang. Dalam penelitian ini GCG diukur dengan ukuran Dewan Komisaris. Ukuran Dewan Komisaris merupakan salah satu fungsi kontrol yang 
terdapat dalam suatu perusahaan. Fungsi kontrol yang dilakukan oleh Dewan Komisaris merupakan salah satu bentuk praktis dan teori agensi. Dalam suatu perusahaan Dewan Komisaris mewakili mekanisme internal utama untuk melaksanakan fungsi pengawasan dalam principal dan mengontrol perilaku opportunitis manajemen. Perusahaan yang mempunyai persentase Dewan Komisaris eksternal lebih rendah akan mempunyai pengawasan yang rendah terhadap kinerja perusahaan (Astuti dan Zahrotun, 2007 dalam Addiyah dan Chariri, 2014). Semakin besar ukuran dewan komisaris dalam suatu perusahan maka semakin rendah kemungkinan perusahaan mengalami kondisi tekanan keuangan. Dengan semakin banyak jumlah dewan komisaris, maka fungsi monitoring terhadap kebijakan direksi dapat dijalankan dengan lebih baik lagi, sehingga perusahaan akan terhidar dari kesulitan keuangan (Whardani, 2008). Semakin banyaknya anggota dewan komisaris, pengawasan semakin baik untuk meningkatkan kinerja perusahaan.

H2: Good Corporate Governance berpengaruh positif dan signifikan terhadap Kinerja Keuangan

\subsubsection{Pengaruh Ukuran Perusahaan terhadap Kinerja Keuangan}

Ukuran perusahaan merupakan hal yang penting dalam proses pelaporan keuangan. Ukuran peruahaan dalam hal ini diukur dengan melihat seberapa besar asset yang dimiliki oleh sebuah perusahaan. Asset yang dimiliki perusahaan ini menggambarkan hak dan kewajiban serta permodalan perusahaan.

Ukuran perusahaan akan berpengaruh terhadap perkembangan perusahaan (Darmawati, 2004) menyatakan bahwa perusahaan besar pada dasarnya memiliki kekuatan finansial dalam menunjang kinerja. Hesti (2010) dalam penelitiannya menemukan bukti bahwa ukuran perusahaan berpengaruh positif signifikan terhadap kinerja keuangan perusahaan. Perusahaan dengan asset besar biasanya akan mendapatkan perhatian lebih dari masyarakat, hal ini akan menyebabkan perusahaan lebih berhati-hati dalam melakukan pelaporan keuangannya. Perusahaan diharapkan akan selalu berusaha menjaga stabilitas kinerja keuangan mereka.

H3: Ukuran Perusahaan berpengaruh positif dan signifikan terhadap Kinerja Keuangan

\section{METODE PENELITIAN}

\subsection{Populasi dan Sampel}

Populasi yang digunakan dalam penelitian ini adalah semua perusahaan perbankan yang terdaftar di BEI pada periode 2015-2019. Penulis memilih meneliti perusahaan perbankan karena perusahaan perbankan memiliki keharusan yang cukup tinggi dalam pengelolaan dana, baik dana pemilik maupun dana masyarakat dan sumber daya dalam menciptakan nilai dalam perusahaan yang dapat mempengaruhi kinerja keuangan perusahaan.

Tabel 3.1 Proses Pemilihan Sampel

\begin{tabular}{|l|l|c|}
\hline No & \multicolumn{1}{|c|}{ Kriteria } & Jumlah Perusahaan \\
\hline 1. & $\begin{array}{l}\text { Perusahaan perbankan yang terdaftar di BEI } \\
\text { secara berturut-turut periode 2015-2019 }\end{array}$ & 45 \\
\hline 2. & $\begin{array}{l}\text { Perusahaan yang tidak menerbitkan laporan } \\
\text { keuangan yang diaudit dan dipublikasikan } \\
\text { pada periode 2015-2019 }\end{array}$ & (17) \\
\hline 3. & $\begin{array}{l}\text { Perusahaan yang tidak menggunakan mata } \\
\text { uang Rupiah }\end{array}$ & $\begin{array}{l}\text { Perusahaan tidak memiliki data lengkap terkait } \\
\text { dengan variabel-variabel yang digunakan }\end{array}$ \\
\hline 4. &
\end{tabular}




\begin{tabular}{|l|l|c|}
\hline & Jumlah Sampel Akhir & 20 \\
\hline & TahunPenelitian & 5 \\
\hline & Total Sampel Penelitian & 100 \\
\hline
\end{tabular}

\subsection{Operasionalisasi Variabel}

Adapun operasional variabel-variabel yang digunakan dalam penelitian ini adalah sebagai berikut:

\subsubsection{Kinerja Keuangan}

Indikator yang digunakan untuk menghitung kinerja keuangan dalam penelitian ini adalah Return On Asset (ROA). Alasan dipilihnya ROA sebagai ukuran kinerja keuangan adalah karena ROA digunakan untuk mengukur efektifitas perusahaan dalam menghasilkan keuntungan dengan memanfaatkan aktiva yang dimilikinya. ROA dihitung dengan rumus sebagai berikut:

\subsubsection{Intellectual Capital (X1)}

$$
\text { ReturnOnAsset }=\frac{\text { Laba Bersih }}{\text { Total Asset }} \times 100 \%
$$

Pengukuran intellectual capital dalam penelitian ini diukur dengan metode VAIC $^{\mathrm{TM}}$. Metode VAIC ${ }^{\mathrm{TM}}$ ini dipilih karena metode ini lebih efektif menilai intellectual capital yang terdiri dari capital employed/physical capital, human capital, structural capital, dan metode perhitungan ini dapat di peroleh pada laporan keuangan perusahaan. Ulum (2009:90) menyebutkan bahwa pengukuran $\mathrm{VAIC}^{\mathrm{TM}}$ mengindikasikan kemampuan intelektual organisasi yang dapat dianggap sebagai Business Performance Indicator.

Metode VAIC $^{\mathrm{TM}}$ dimulai dengan kemampuan perusahaan untuk menciptakan Value Added (VA). Menurut Ulum (2009:87) VA adalah indikator paling objektif untuk menilai keberhasilan bisnis dan menunjukkan kemampuan perusahaan dalam penciptaan nilai (value creation). VA dihitung dengan rumus sebagai berikut:

$$
\mathrm{VA}=\mathbf{O P}+\mathbf{E C}+\mathbf{D}+\mathbf{A}
$$

Keterangan :

$\mathrm{OP}=$ Operating Profit (laba Operasi)

$\mathrm{EC}=$ Employe Costs (Beban Karyawan)

$\mathrm{D}=$ Depreciation (Depresiasi)

A $=$ Amortisation (Amortisasi)

Setelah perhitungan VA tahap selanjutnya adalah menghitung komponen $\mathrm{VAIC}^{\mathrm{TM}}$, berikut penjelasan komponen-komponen tersebut:

a. Value Added Capital Employed (VACA)

Capital Employed atau disebut juga Physical Capital merupakan modal fisik yang digunakan perusahaan atau dana yang tersedia berupa ekuitas dan laba bersih yang dapat mendukung berlangsungnya kegiatan operasional perusahaan. VACA adalah indikator untuk VA yang diciptakan oleh satu unit dari Physical Capital. Rasio ini menunjukkan kontribusi yang dibuat oleh setiap unit dari CE terhadap value added organisasi. VACA diukur dengan rumus sebagai berikut:

Keterangan:

$$
\mathrm{VACA}=\frac{V A}{C E}
$$

$\mathrm{CE} \quad=$ Dana yang tersedia (Jumlah ekuitas dan laba bersih)

$\mathrm{VA}=$ Value Added 
Value Added Human Capital (VAHU

Value Added Human Capital (VAHU) mengacu pada nilai kolektif dari modal intelektual perusahaan yaitu kompetensi, pengetahuan dan keterampilan. VAHU menunjukkan berapa banyak VA dapat dihasilkan dengan dana yang dikeluarkan untuk tenaga kerja. Rasio ini menunjukkan kontribusi yang dibuat oleh setiap rupiah yang diinvestasikan dalam HC terhadap value added organisasi. VAHU diukur dengan rumus sebagai berikut:

$$
\text { VAHU }=\frac{V A}{H C}
$$

Keterangan :

$\mathrm{VA}=$ Value Added

$\mathrm{HC}=$ Gaji dan tunjangan karyawan

Structural Capital Value Added (STVA)

Sructural Capital Value Added (STVA) didefenisikan sebagai competitive intelligence, formula, sistem informasi,hak paten, kebijakan, proses, dan sebagainya, hasil dari produk atau sistem perusahaan yang telah diciptakan dari waktu ke waktu. Rasio ini mengukur jumlah SC yang dibutuhkan untuk menghasilkan 1 Rupiah dari VA dan merupakan indikasi bagaimana keberhasilan SC dalam penciptaan nilai. STVA diukur dengan rumus sebagai berikut:

$$
\text { STVA }=\frac{S C}{V A}
$$

Keterangan:

$\mathrm{SC} \quad=\mathrm{VA}-\mathrm{HC}$

$\mathrm{VA}=$ Value Added

Rasio terakhir dalam menghitung intellectual capital adalah Value Added Intellectual Coeffecient $\left(\mathrm{VAIC}^{\mathrm{TM}}\right)$, dengan menjumlahkan ketiga komponen diatas yaitu VACA, VAHU, dan STVA. Formulasi dari perhitungan $\mathrm{VAIC}^{\mathrm{TM}}$ adalah sebagai berikut:

\section{VAIC $^{\mathrm{TM}}=$ VACA+VAHU + STVA}

Keterangan:

$\mathrm{VAIC}^{\mathrm{TM}}=$ Value Added Intellectual Coefficient

VACA $=$ Value Added Capital Employed

VAHU $=$ Value Added Human Capital

STVA = Value Added Structural Capital

\subsubsection{Good Corporate Governance (X2)}

Dalam penelitian ini, good corporate governance diukur dengan menggunakan Ukuran Dewan Komisaris. Alasan menggunakan ukuran dewan komisaris GCG adalah karena dewan komisaris sebagai organ perusahaan yang bertugas dan bertanggung jawab secara kolektif untuk melakukan pengawasan dan memberikan nasehat kepada direksi. Ukuran dewan komisaris diukur dengan menggunakan indikator jumlah anggota dewan komisaris suatu perusahaan (Darwis, 2009).

$$
\text { Ukuran (Proporsi) Dewan Komisaris: } \frac{\text { Jumlah Dewan Komisaris Independen }}{\text { Total Jumlah Dewan Komisaris }}
$$

\subsubsection{Ukuran Perusahaan}

Ukuran perusahaan merupakan tingkat identifikasi besar kecilnya suatu perusahaan. Variabel ukuran perusahaan (SIZE) diukur dengan dengan menggunakan logaritma natural (Ln) 
dari total asset (Susanti dan Santosa 2011). Hal ini dikarenakan besar total asset masing-masing perusahaan berbeda, bahkan dapat memilih selisih yang besar.

\subsection{Analisis Regresi Berganda}

Ukuran Perusahaan $=$ Ln (Total Asset)

Metode yang digunakan dalam penelitian ini menggunakan model regresi berganda. Analisis regresi linier berganda adalah regresi linier untuk menganalisis besarnya hubungan dan pengaruh variabel independen yang jumlahnya lebih dari dua (Suharyadi dan Purwanto, 2004:508). Persamaan regresi pada penelitian ini dapat dituliskan sebagai berikut:

$$
Y=a+b_{1} X_{1}+b_{2} X_{2}+b_{3} X_{3}+e
$$

Dimana:

$$
\begin{aligned}
& \mathrm{Y}=\text { Kinerja Keuangan }(\mathrm{ROA}) \\
& \text { a } \quad=\text { Konstanta } \\
& \mathrm{X} 1=\text { Intellectual Capital } \\
& \text { X2 = Good Corporate Governance } \\
& \text { X3 = Ukuran Perusahaan } \\
& \text { b1, b2b3 = Koefisien Regresi } \\
& \text { e } \quad=\text { Error tern (Kesalahan Pengguna) }
\end{aligned}
$$

HASIL PENELITIAN DAN PEMBAHASAN

\subsection{Statistik Deskriptif}

Tabel 4.5 Hasil Pengujian Statistik Deskriptif

\begin{tabular}{|l|r|r|r|r|r|}
\hline & \multicolumn{1}{|c|}{$\mathrm{N}$} & \multicolumn{1}{|c|}{ Minimum } & Maximum & \multicolumn{1}{c|}{ Mean } & \multicolumn{1}{c|}{ Std. Deviation } \\
\hline VAICTM & 100 & 1,1352 & 10,6067 & 3,866730 & 1,7201464 \\
GCG & 100 & 33,33 & 100,00 & 57,6655 & 12,09423 \\
SIZE & 100 & 22,63 & 37,10 & 27,3648 & 3,69237 \\
ROA & 100 &, 0013 &, 0392 &, 013261 &, 0088353 \\
Valid N (listwise) & 100 & & & & \\
\hline
\end{tabular}

Sumber: Hasil Output SPSS 22 (data diolah)

Berdasarkan tabel 4.5 diatas dihasilkan jumlah data sebanyak 100 data. Intellectual Capital $\left(\mathrm{VAIC}^{\mathrm{TM})}\right.$ memiliki nilai minimum sebesar 1,1352 yang dimiliki oleh Bank Pembangunan Daerah Jawa Timur Tbk pada tahun 2015 dan nilai maximum sebesar 10,6067 dimiliki oleh Bank Permata Tbk pada tahun 2014 dan diperoleh nilai mean sebesar 3,866730 dan nilai Standard Deviation sebesar 1,7201464 .

Good Corporate Governance (Dewan Komisaris) memiliki nilai minimum sebesar 33,33 yang dimiliki oleh Bank Permata Tbk tahun 2015 dan Bank Mega Tbk tahun 2015, sedangkan nilai maximum sebesar 100,00 Bank Maspion Indonesia Tbk pada tahun 2016 dan Bank National Nobu Tbk tahun 2017 sampai 2019. Nilai Mean sebesar 57,6655 dan nilai Standard Deviation sebesar 12,09423 .

Ukuran Perusahaan memiliki rata-rata sebesar 27,3648 dan nilai Standard Deviation 3,69237. Nilai maximum ada pada perusahaan Bank Mestika Darma Tbk sebesar 37,10\%, sedangkan nilai minimum adalah Bank National Nobu Tbk sebesar 22,63\%. 
Return On Assets (ROA) memiliki nilai maximum 0,0392 (3,92\%) yang dimiliki oleh Bank Permata Tbk pada tahun 2016, dan nilai minimum yaitu sebesar 0,0013 $(0,13 \%)$ dimiliki oleh Bank Bukopin Tbk pada tahun 2017. Nilai Mean 0,01346 dan nilai Standard Deviation sebesar $0,0088353(0,88353 \%)$.

\subsection{Pengujian Hipotesis}

Tabel 4.8 Hasil Pengujian Analisis Regresi Linier Berganda

\begin{tabular}{|c|c|c|c|c|c|}
\hline \multirow[b]{2}{*}{ Model } & \multicolumn{2}{|c|}{ Unstandardized Coefficients } & \multirow{2}{*}{$\begin{array}{c}\begin{array}{c}\text { Standardized } \\
\text { Coefficients }\end{array} \\
\text { Beta }\end{array}$} & \multirow[b]{2}{*}{$\mathrm{T}$} & \multirow[b]{2}{*}{ Sig. } \\
\hline & $\mathrm{B}$ & Std. Error & & & \\
\hline (Constant) & ,867 &, 531 & & ,892 & \\
\hline VAICTM & ,970 & 620 & ,304 & 3,234 & \\
\hline GCG &, 108 &, 030 &, 106 & 2,216 & \\
\hline SIZE &, 320 & 290 & 137 & 1,451 & \\
\hline
\end{tabular}

a. Dependent Variable: ROA

Sumber: Hasil Output SPSS 22 (data diolah)

berikut:

Berdasarkan tabel tersebut, maka persamaan regresi yang terbentuk adalah sebagai

Sumber: Hasil Output SPSS 22 (data diolah) berikut:

Berdasarkan tabel tersebut, maka persamaan regresi yang terbentuk adalah sebagai

Keterangan:

$$
\mathrm{ROA}=0,867+0,970 \mathrm{VAIC}^{\mathrm{TM}}+\mathbf{0 , 1 0 8} \mathrm{GCG}+0,320 \mathrm{SIZE}+\varepsilon
$$

a. Nilai Konstanta sebesar 0,867 menjelaskan bahwa jika variabel Value Added Intellectual Coefficient (VAIC ${ }^{\mathrm{TM}}$ ), Good Corporate Governance (GCG), dan Ukuran Perusahaan dianggap konstan, maka tingkat Return On Assets (ROA) akan meningkat sebesar 0,867.

b. Koefisien regresi Value Added Intellectual Coefficien (VAIC ${ }^{\mathrm{TM}}$ ) adalah0,970 artinya Value Added Coefficien (VAIC ${ }^{\mathrm{TM}}$ ) berpengaruh positif secara parsial terhadap Kionerja Keuangan sebesar 0,970 atau 97\%.

c. Koefisien regresi Good Corporate Governance adalah 0,108 artinya Good Corporate Governance berpengaruh positif secara parsial terhadap Kionerja Keuangan sebesar 0,108 atau 10,8\%.

d. Koefisien regresi Ukuran Perusahaan adalah 0,320 artinya Ukuran Perusahaan tidak berpengaruh signifikan secara parsial terhadap Kinerja Keuangan sebesar 0,320 atau $32 \%$.

\subsubsection{Analisis Koefisien Determinasi (R2)}

\section{Tabel 4.9 Hasil Pengujian Koefisien Determinasi}

\begin{tabular}{|l|r|r|r|r|}
\hline Model & R & \multicolumn{1}{|c|}{ R Square } & Adjusted R Square & Std. Error of the Estimate \\
\hline 1 &, $636^{\mathrm{a}}$ &, 575 &, 528 &, 63378 \\
\hline
\end{tabular}

a. Predictors: (Constant), SIZE, VAICTM, GCG

b. Dependent Variable: ROA 
Sumber: Hasil Output SPSS 22 (data diolah)

Dari tabel 4.9 diatas diperoleh nilai koefisien determinasi (R Square) sebesar 0,575 atau $57,5 \%$ artinya variabel Independen (Intellectual Capital, Good Corporate Governance, dan Ukuran Perusahaan) secara simultan mempengaruhi variabel Dependen yaitu Ukuran Perusahaan sebesar 57,5\% sedangkan sisanya 42,5\% dipengaruhi oleh variabel lain yang tidak diteliti dalam penelitian ini. Standard Error of Estimate (SEE) sebesar 0,63378 dimana semakin kecil nilai SEE akan membuat model regresi semakin tepat dalam memprediksi variabel Dependen.

\subsubsection{Uji Parsial (Uji Statisik t)}

Tabe 4. 10 Hasil Uji parsial (Uji Statistik t)

\begin{tabular}{|c|c|c|c|c|c|}
\hline \multirow[b]{2}{*}{ Model } & \multicolumn{2}{|c|}{ Unstandardized Coefficients } & \multirow{2}{*}{$\begin{array}{c}\begin{array}{c}\text { Standardized } \\
\text { Coefficients }\end{array} \\
\text { Beta }\end{array}$} & \multirow[b]{2}{*}{$\mathrm{T}$} & \multirow[b]{2}{*}{ Sig. } \\
\hline & $\mathrm{B}$ & Std. Error & & & \\
\hline (Constant) & ,867 &, 531 & & ,892 &, 375 \\
\hline VAICTM & ,970 & ,620 & ,304 & 3,234 & ,002 \\
\hline GCG &, 108 &, 030 & , 106 & 2,216 & ,031 \\
\hline SIZE & ,320 & -290 & 137 & 1,451 & , 150 \\
\hline
\end{tabular}

a. Dependent Variable: ROA

Sumber: Hasil Output SPSS 22 (data diolah)

Berdasarkan hasil uji parsial pada tabel 4.10 diatas, variabel value added Intellectual Coefficient $\left(\mathrm{VAIC}^{\mathrm{TM}}\right.$ ) berpengaruh positif dan signifikan terhadap kinerja keuangan, karna dihasilkan nilai $t_{\text {hitung }}>\mathrm{t}_{\text {tabel }}(3,234>1,9872)$ dengan tingkat signifikan lebih kecil dari 0,05 (5\%). Dengan demikian Ho dalam penelitian ini ditolak dan H1 diterima. Sehingga dapat disimpulkan bahwa variabel Intellectual Capital yang diukur dengan menggunakan Value Added Intellectual Coefficient (VAIC $^{\mathrm{TM}}$ ) mempunyai pengaruh positif dan signifikan terhadap kinerja keuangan yang diukur dengan Return on Assets (ROA).

Berdasarkan hasil uji parsial pada tabel 4.10 diatas, variabel GCG berpengaruh positif dan signifikan terhadap Kinerja Keuangan, karena dihasilkan nilai $t_{\text {hitung }}>\mathrm{t}_{\text {tabel }}$ $(2,216>1,9872)$ dengan tingkat signifikansi lebih kecil dari $5 \%(0,031<0,05)$. Dengan demikian dalam penilitian ini Ho ditolak dan $\mathrm{H} 2$ diterima. Maka dapat disimpulkan variabel Good Corporate Governance yang diukur dengan menggunakan ukuran Dewan Komisaris berpengaruh positif dan signifikan terhadap kinerja keuangan yang diukur dengan Return On Assets (ROA).

Variabel Ukuran Perusahaan tidak berpengaruh signifikan terhadap Kinerja Keuangan karna dihasilkan nilai $t_{\text {hitung }}<t_{\text {tabel }}(0,1451<1,9872)$ dengan tingkat signifikan $(0,150>0,05)$. Dengan demikian Ho dalam penelitian ini diterima dan H3 ditolak. Maka dapat disimpulkan variabel Ukuran Perusahaan tidak berpengaruh signifikan terhadap kinerja keuangan yang diukur dengan Return On Assets (ROA).

\subsubsection{Uji Simultan (Uji Statistik F)}

Pengujian ini dimaksudkan untuk mengetahui pengaruh antara variabel independen terhadap variabel dependen secara bersama-sama (simultan). Signifikan model regresi secara simultan diuji dengan melihat perbandingan antara $F_{\text {tabel }}$ dengan $F_{\text {hitung. Jika nilai }}$ $F_{\text {hitung }}>F_{\text {tabel }}$ dan jika nilai signifikan lebih kecil dari 0,05 maka variabel independen dinyatakan berpengaruh terhadap variabel dependen. Hasil penelitian ditunjukkan pada tabel berikut ini:

\section{Tabel 4.11 Hasil Uji Simultan (Uji Statistik F)} ANOVA $^{\mathrm{a}}$

\begin{tabular}{|l|l|l|l|l|l|}
\hline Model & Sum of Squares & Df & Mean Square & F & Sig. \\
\hline
\end{tabular}




\begin{tabular}{|ll|r|r|r|r|r|}
\hline 1 & Regression &, 001 & 3 &, 000 & 5,850 &, $001^{\mathrm{b}}$ \\
Residual &, 007 & 96 &, 000 & & \\
Total &, 008 & 99 & & & \\
\hline
\end{tabular}

a. Dependent Variable: ROA

a. Predictors: (Constant), SIZE, VAICTM, GCG

Sumber: Hasil Output SPSS 22 (data diolah)

Berdasarkan tabel 4.11 diatas diperoleh $F_{\text {hitung }}$ sebesar 5,850 lebih besar dari $F_{\text {tabel }}$ yaitu sebesar 3,10 serta nilai signifikansi yang diperoleh lebih kecil dari 0,05 (5\%) dengan demikian variabel Intellectual Capital, Good Corporate Governance, dan Ukuran Perusahaan secara simultan berpengaruh positif dan signifikan terhadap Kinerja Keuangan yang diukur dengan Return On Assets (ROA).

Value Added yang tinggi memiliki peran yang kuat untuk meningkatkan kinerja keuangan yang bersumber dari capital employed, human capital, dan structural capital. Sehingga hipotesis yang menyatakan bahwa intellectual capital (VAIC ${ }^{\mathrm{TM}}$ ) berpengaruh secara positif terhadap kinerja keuangan, diterima.

Menurut teori Stakeholder dalam buku Ulum (2009:6) menyatakan bahwa pengelolan yang baik atas human capital, capital employed/physical capital, dan structural capital akan menciptakan value added bagi perusahaan yang kemudian dapat mendorong kinerja keuangan perusahaan yang merupakan orientasi para Stakeholder. Hal ini dapat dilihat pada Bank Negara Indonesia (persero) Tbk tahun 2015-2016 dimana intellectual capital (VAIC ${ }^{\mathrm{TM}}$ ) yang dihasilkan naik $(3,5025$ dan 4,3352) dan kinerja keuangan mengalami peningkatan.

\subsection{Pembahasan}

\subsubsection{Pengaruh Intellectual Capital terhadap Kinerja Keuangan}

Berdasarkan hasil koefisien regresi, dan uji t variabel intellectual capital yang diukur dengan menggunakan $\mathrm{VAIC}^{\mathrm{TM}}$ berpengaruh positif dan signifikan terhadap kinerja keuangan. Hal ini dikarenakan Intellectual Capital mampu menciptakan Value Added dalam suatu perusahaan, diterima. Hasil penelitian ini sejalan dengan teori stakeholder yang menyatakan bahwa pengelolaan yang baik atas pengelolan yang baik atas human capital, capital employed/physical capital, dan structural capital akan menciptakan value added bagi perusahaan yang kemudian dapat mendorong kinerja keuangan perusahaan, dan penelitian ini juga konsisten dengan hasil penelitian yang dilakukan oleh Saragih (2017), Pratiwi (2017) Untara dan Titik (2014) dengan hasil penelitian diperoleh intellectual capital berpengaruh positif dan signifikan terhadap Kinerja Keuangan.

\subsubsection{Pengaruh Good Corporate Governance terhadap Kinerja Keuangan}

Berdasarkan nilai koefisien regresi, dan uji nilai t variabel Good Corporate Governance (GCG) diatas maka GCG yang diukur dengan menggunakan ukuran Dewan Komisaris Good Corporate Governance berpengaruh positif dan signifikan terhadap kinerja keuangan. Hasil penelitian ini sesuai dengan teori yang menyatakan bahwa Ukuran Dewan Komisaris berpengaruh positif terhadap Kinerja Keuangan, diterima. Kondisi ini terjadi karna dengan banyaknya jumlah anggota dewan komisaris, maka pengawasan terhadap dewan direksi menjadi lebih baik, nasehat dan masukan untuk dewan direksi pun menjadi lebih banyak. Sehingga kinerja dari manajemen menjadi lebih baik dan berimbas pula pada meningkatnya kinerja perusahaan yakni semakin banyak jumlah dewan komisaris dalam suatu perusahaan, maka pengawasan terhadap manajemen dan dewan direksi akan lebih ketat. Semakin banyaknya dewan komisaris maka masukan terhadap 
dewan direksi juga semakin banyak sehingga opsi yang diperoleh dewan direksi semakin banyak. Oleh karena itu penambahan jumlah dewan komisaris akan meningkatkan kinerja perusahaan.

Hasil penelitian ini juga mendukung peraturan BEJ (Bursa Efek Jakarta) yang sekarang menjadi Bursa Efek Indonesia (BEI) yang mengatur tentang rasio Dewan Komisaris Independen. Dengan ketentuan bahwa jumlah komisaris independen sekurangkurangnya 30\% dari jumlah seluruh anggota komisaris. Artinya semakin tinggi proporsi dewan komisaris independen akan semakin ketat kegiatan monitoring yang dilakukan oleh komisaris independen. Penelitian ini juga konsisten dengan hasil penelitian yang dilakukan oleh Pratiwi (2017) yang menyatakan bahwa Good Corporate Governance berpengaruh positif terhadap Kinerja Keuangan. Oleh karena itu masalah kepentingan antara pemegang saham minoritas dan pemegang saham mayoritas (pengendali) akan efektif dilakukan. Dengan demikian perusahaan akan mampu meningkatkan kinerja perusahaannya.

\subsubsection{Pengaruh Ukuran Perusahaan terhadap Kinerja Keuangan}

Ukuran Perusahaan merupakan tingkat identifikasi besar kecilnya suatu perusahaan (SIZE) yang diukur dengan menggunakan Ln (Logaritma Natural) dari total asset pada tahun penelitian. Berdasarkan hasil analisis hasil uji t hipotesis ketiga yang menyatakan Ukuran Perusahaan berpengaruh signifikan terhadap Kinerja Keuangan, ditolak. Penelitian ini juga sesuai dengan hasil penelitian yang dilakukan oleh penelitian Gunawan dkk, (2019) juga dengan hasil penelitian diperoleh Ukuran Perusahaan tidak berpengaruh signifikan terhadap Kinerja Keuangan. Dengan demikian perusahaan belum cukup optimal dalam mengelola aset yang dimiliki untuk meningkatkan kinerja keuangannya dan ukuran perusahaan tidak bisa digunakan sebagai jaminan bahwa perusahaan yang besar memiliki kinerja yang baik.

\section{KESIMPULAN DAN SARAN}

\subsection{Kesimpulan}

Berdasarkan analisis dan pembahasan diatas, maka diperoleh kesimpulan sebagai berikut:

1. Intellectual Capital berpengaruh positif dan signifikan terhadap Kinerja Keuangan.

2. Good Corporate Governance berpengaruh positif dan signifikan terhadap Kinerja Keuangan.

3. Ukuran Perusahaan tidak berpengaruh signifikan terhadap Kinerja Keuangan.

4. Intellectual Capital, Good Corporate Governance, dan Ukuran Perusahaan secara simultan berpengaruh positif dan signifikan terhadap Kinerja Keuangan

\subsection{Saran}

Bagi peneliti selanjutnya sebaiknya menambah variabel yang mempengaruhi kinerja keuangan seperti Current ratio, Debt to eduity ratio.

\section{DAFTAR PUSTAKA}

Addiyah, Alina dan A. Chariri. 2014. Pengaruh Penerapan Corporate Governance Terhadap Kinerja Keuangan Perbankan (Studi pada Perusahaan Perbankan yang Terdaftar di Bursa Efek Indonesia (BEI) Tahun 2010-2012. Diponegoro Journal of Accounting, Vol. 3, No.4

Andriana, Denny. 2014. Pengaruh Intellectual Capital terhadap Kinerja Keuangan Perusahaan. Jurnal Riset Akuntansi dan Keuangan 
Arief, M. Izhar, Erlina, I. Yahya. 2014. Pengaruh Modal Intelektual Terhadap Nilai Perusahaan dengan Kinerja Keuangan sebagai Variabel Intervening pada Perusahaan Perbankan yang Terdaftar di Bursa Efek Indonesia. Jurnal Telaah dan Riset Akuntansi Vol, 7 No.2

Bank Indonesia. 2006. Peraturan Bank Indonesia Nomor 8/4/PBI/2006. tentang Pelaksanaan Good Corporate Governance (GCG) bagi Bank umum

Bank Indonesia 2013. Surat Edaran Bank Indonesia Nomor 15/15/DPNP tanggal 29 April 2013. Perihal Pelaksanaan Good Corporate Governance bagi Bank Umum

Bank Indonesia. 2013. Kondifikasi Peraturan Bank Indonesia Manajemen Good Corporate Governance

Boekestein, Bram. 2006. The Relation Between Intellectual Capital and Intangible Assets of Pharmaceutical Companies.Journal of Intellectual Capital, Vol.7 No.2

Brigham dan Houston. 2012. Dasar-dasar Manajemen Keuangan. Salemba Empat: Jakarta

Bukh, P. N. 2003. Commentary: The Relevance of Intellectual Capital Disclosure:A Paradox. Accounting, Auditing \& Accountability Journal Vol. 16, No.1

Bukh, P., Nielsen, C., Gormsen, P., and Mouritsen, J. 2005. Disclosure of Information on Intellectual Capital in Danish IPO Prospectuses. Accounting, Auditing \& Accountability Journal Vol. 18, No. 6

Darmawati. 2004. Hubungan Corporate Governance dan Kinerja Perusahaan. Jurnal Riset Akuntansi Indonesia Vol.8, No.1

Darwis, Herman. 2009. Corporate Governance Terhadap Kinerja Perusahaan. Jurnal Keuangan dan Perbankan Vol. 13, No. 3

Effendi, Arief. 2009. The Power Of Good Corporate Governance. Salemba Empat: Jakarta

Gunawan, H. Henry, Y. J. Pambelum, dan L. M. Angela. 2019. Pengaruh Corporate Governance, Intellectual Capital, Leverage dan Ukuran Perusahaan Terhadap Kinerja Keuangan Perbankan. Jurnal Akuntansi dan Governance Andalas Vol.2, No.1

Hesti, Diah Aristya. 2010. Analaisis Pengaruh Ukuran Perusahaan, Kecukupan Modal, Kualitas Aktiva Produktif, dan Likuiditas Terhadap Kinerja Keuangan. Univeristas Diponegoro

Ikatan Akuntansi Indonesia. 2009. Standar Akuntansi Keuangan. Salemba Empat: Jakarta

Jumingan. 2006. Analisis Laporan Keuangan, Cetakan Pertama. Jakarta: Bumi Aksara.

Komite Nasional Kebijakan Governance (KNKG). 2006. Pedoman Umum Good Corporate Governance Indonesia. 
Mengginson. 1997. Corporate Finance Theory. Addison-Wesley Educational Publisher Inc.

Muna, Nalal. 2014. Pengaruh Intellectual Capital terhadap Return Saham melalui Kinerja Keuangan Perusahaan Real Estate dan Properti. Universitas Diponegoro

Nizamullah, Darwanis, S. Abdullah. 2014. Pengaruh Penerapan Good Corporate Governance Terhadap Kinerja Keuangan (Studi Empiris PadaPerusahaan Perbankan yang Terdaftar di Bursa Efek Indonesia 2010-2012). Jurnal Akuntansi Program Pascasarjana Universitas Syiah Kuala Vol. 3, No. 2

Otoritas Jasa Keuangan. 2016. Peraturan Otoritas Jasa Keuangan Nomor 55/POJK.03/2016. Tentang penerapan Tata Kelola bagi Bank Umum

Pratiwi, Tia Rizna. 2017. Pengaruh Intellectual Capital dan Corporate Governance terhadap Kinerja Keuangan. Jurnal Akuntansi dan Keuangan Vol. 8, No. 1

Puspitasari, Filia dan E. Ernawati. 2010. Pengaruh Mekanisme Corporate Governance Terhadap Kinerja Keuangan Badan Usaha. Jurnal Manajemen Teori dan Terapan Vol.3, No.2.

Retno M., R. Dyah dan D. Priantinah. 2012. Pengaruh Good Corporate Governance dan Pengungkapan Corporate Social Responsibility Terhadap Nilai Perusahaan (Studi Empiris Pada Perusahaan yang Terdaftar di Bursa Efek Indonesia Periode 20072010). Jurnal Nominal Vol. 1 No. 1

Rivandi, Muhammad. 2018. Pengaruh Intellectual Capital Disclosure, Kinerja Keuangan dan Kepemilikan Manajerial Terhadap Kinerja Perusahaan. Jurnal Pundi, Vol.2, No.1

Saragih, Afni Eliana. 2017. Pengaruh Intellectual Capital Terhadap Kinerja Perusahaan Manufaktur yang Terdaftar di Bursa Efek Indonesia. Jurnal Riset Akuntansi dan Keuangan Vol.3, No.1

Stewart, Thomas A. 2010. Intellectual Capital: The New Wealth of Organizations. Doubleday/ Currency, New York, New York, United States of America

Suharyadi dan Purwanto. 2004. Metodologi Penelitian.Jakarta: Gramedia Pustaka Utama.

Susanti, Meri dan E. B. Santosa. 2011. Pengaruh Profitabilitas terhadap Nilai Perusahaan dengan PengungkapanCorporate Social Responsibility sebagai Variabel Moderasi. Kajian Akuntansi, Vol.6, No.2, Desember 2011

Sutedi, Andrian. 2012. Good Corporate Governance. Sinar Grafika: Jakarta

Tjondro, David dan R. Wilopo. 2011. Pengaruh Good Corporate Governance (GCG) Terhadap Profitabilitas dan Kinerja Saham Perusahaan Perbankan yang Tercatat di Bursa Efek Indonesia. Journal of Business and Banking Vol. 1 No. 1

Ulum, Ihyaul. 2009. Capital Konsep dan Kajian Empiris. Graha Ilmu: Yogyakarta 
Untara, A. Permata dan M. Titik. 2014. Pengaruh Modal Intelektual Terhadap Kinerja Keuangan Perusahaan Perbankan yang Terdaftar di BEI. Jurnal Ilmu dan Riset Akuntansi Vol. 3, No. 10

Wardhani, Ratna. 2006. Mekanisme Corporate Governance Dalam Perusahaan Yang Mengalami Permasalahan Keuangan (Financially Distressed Firms). Simposium Nasional Akuntansi IX, Padang. 